U.S. DEPARTMENT OF THE INTERIOR

U.S. GEOLOGICAL SURVEY

\title{
MAGNETIC ANOMALY MAP OF THE CENTRAL CAYMAN TROUGH NORTHWESTERN CARIBBEAN SEA
}

By William P. Dillon, N. Terence Edgar, Lindsay M. Parson, Kathryn M. Scanlon, George R. Driscoll, and Colin L. Jacobs

Prepared in cooperation with the INSTITUTE OF OCEANOGRAPHIC SCIENCES 